\title{
Prevalence and distribution of Angiostrongylus cantonensis (Nematoda, Angiostrongylidae) in Achatina fulica (Mollusca, Gastropoda) in Baixada Santista, São Paulo, Brazil
}

\author{
Laura Rocha Guerino ${ }^{[1],[2]}$, Iracy Lea Pecora ${ }^{[2]}$, Marcel Sabino Miranda ${ }^{[3],}$ \\ Cryslaine Aguiar-Silva ${ }^{[4]}$, Omar dos Santos Carvalho ${ }^{[4]}$, Roberta Lima Caldeira ${ }^{[4]}$ \\ and Reinaldo José da Silva ${ }^{[1]}$
}

\begin{abstract}
[1]. Laboratório de Parasitologia de Animais Silvestres, Departamento de Parasitologia, Universidade Estadual Paulista Júlio de Mesquita Filho, Botucatu, SP, Brasil. [2]. Laboratório de Moluscos, Universidade Estadual Paulista Júlio de Mesquita Filho, São Vicente, SP, Brasil. [3]. Laboratório de Malacologia, Departamento de Biologia Animal, Universidade Estadual de Campinas, Campinas, SP, Brasil. [4]. Laboratório de Helmintologia e Malacologia Médica, Centro de Pesquisas René Rachou, Fundação Oswaldo Cruz, Belo Horizonte, MG, Brasil.
\end{abstract}

\begin{abstract}
Introduction: Angiostrongylus cantonensis causes eosinophilic meningoencephalitis in humans. Worldwide expansion of this nematode is linked to the dispersion of their hosts. This study aimed to determine the prevalence of $A$. cantonensis infection in Achatina fulica in the nine municipalities that make up Baixada Santista, São Paulo, Brazil. Methods: Angiostrongylus cantonensis larvae were analyzed using optical microscopy. We performed polymerase chain reaction and restriction fragment length polymorphism using restriction endonuclease ClaI, directed to the internal transcribed spacer region 2 of $A$. cantonensis larval DNA. Results: Of the 540 snails analyzed, 117 (21.7\%) were infected by A. cantonensis. For morphological and morphometric analyses, 60 larvae were used. Second-stage larvae were, on average, $358.2 \mu \mathrm{m}$ long and $26.4 \mu \mathrm{m}$ wide, while third-stage larvae were, on average, $450 \mu \mathrm{m}$ long and $21.12 \mu \mathrm{m}$ wide. The tails of the larvae ended in a fine tip. Conclusions: All municipalities comprising Baixada Santista had A. fulica that were naturally infected with A. cantonensis. All of the observed characteristics were typical of the species.
\end{abstract}

Keywords: Rat lungworm. Giant African snail. Eosinophilic meningitis. Nematode. Emerging parasitosis.

\section{INTRODUCTION}

Two of the 19 species from the Angiostrongylus genus can infect humans: Angiostrongylus costaricensis (Morera \& Céspedes, 1971), which causes abdominal angiostrongyliasis ${ }^{1}$ and Angiostrongylus cantonensis (Chen, 1935), which is the etiologic agent of eosinophilic meningoencephalitis, also called rat lungworm ${ }^{2}$. A . cantonensis has been observed in several regions of the world ${ }^{3-7}$, and they were distributed from Eastern Asia to other continents by two main hosts: rats (definitive hosts) and Achatina fulica Bowdich, 1822 (one of the intermediate hosts), especially during the Second World War ${ }^{8}$. Several species of land and freshwater snails have also been found to be naturally infected with $A$. cantonensis $^{9-14}$.

In Brazil, the occurrence of $A$. cantonensis has been reported in all states except for Acre ${ }^{9-17}$. Man, being an accidental host,

Corresponding author: Dra. Laura Rocha Guerino.

e-mail: laurargue@ig.com.br

Received 18 August 2016

Accepted 6 December 2016 acquires parasitosis when eating foods contaminated with stagethree larvae (L3), raw or undercooked mollusks, and paratenic hosts such as shrimp, frogs, fish, and flatworms ${ }^{4,18-20}$, as well as crabs and lizards ${ }^{21,22}$. In humans, these parasites migrate to the central nervous system (CNS), where they die in the meninges, causing inflammatory reactions $\mathrm{s}^{2324}$.

Achatina fulica plays a crucial role in the global dispersion of $A$. cantonensis ${ }^{1,8,22,25,26}$, since it is present in most areas where this nematode is endemic. These mollusks are associated with an anthropic environment, and once established, their population can significantly increase ${ }^{27}$. Remains of human activity favor the adaptation of this mollusk, as such remains provide food and shelter ${ }^{28}$. In Brazil, this mollusk has high potential to be involved in the transmission of $A$. cantonensis owing to its wide distribution, including to different ecosystems ${ }^{29-31}$.

In the present study, the role of A. fulica as an intermediate host for $A$. cantonensis in the municipalities comprising Baixada Santista, São Paulo State, Brazil, was investigated. 


\section{METHODS}

Samples were collected from January to July, 2012. Specimens were captured in vacant lots in urban areas or where there were forest fragments or waste remains from 90 sites in the nine municipalities comprising Baixada Santista, São Paulo State: Bertioga, Cubatão, Guarujá, Itanhaém, Mongaguá, Santos, São Vicente, Peruíbe, and Praia Grande (Figure 1). Six adult snails were collected from ten sites in each municipality, for a total of 540 individuals. All 90 sites were characterized as to sanitary and georeferenced conditions. After identification of the snail, performed in accordance to Simone ${ }^{32}$, the digestion procedure of mollusks was individually performed in accordance with methods of Wallace and Rosen ${ }^{33}$, followed by the Baermann method ${ }^{34}$. A. cantonensis larvae were then counted and subjected to molecular analysis. The DNA was extracted from the pool of larvae from each snail using the Wizard Genomic DNA Purification Kit (Promega), according to the manufacturer's instructions. The deoxyribonucleic acid (DNA) was subjected to polymerase chain reaction associated with restriction fragment length polymorphism (PCR-RFLP), and the primers used were directed to the internal transcribed spacer region 2 (ITS2) of ribossomal DNA (rDNA). NC1 (forward; 5'ACGTCTGGTTCAGGGTTGTT-3') and NC2 primers (reverse: 5'-TTAGTTTCTTTTCCTCCGCT-3') were designed by Gasser ${ }^{35}$ and anchored in the conserved regions in the final portion of subunit $5.8 \mathrm{~S}$ and the initial portion of subunit 28S. Further, cleavage of this amplicon was performed with endonuclease ClaI (Biolabs) and the profiles were compared to those of A. cantonensis and A. costaricensis established by Caldeira ${ }^{36}$. For morphological and morphometric analysis, 60 larvae were used, which were fixed in $70 \%$ ethanol, clarified with Amann lactophenol, and analyzed (Leica Application Suite LAS V 3.8 Software and DMB 5000 Leica $^{\circledR}$ microscope, Leica Microsystems, Wetzlar, Germany). The taxonomic identification of nematodes was based on morphological and morphometric parameters established by $\mathrm{Ash}^{37}$ and $\mathrm{Lv}^{10}$. The SADIE index ${ }^{38}$ was used to analyze the spatial patterns of the percentage of infected specimens from geographical coordinates and the percentage of infected A. fulica.

\section{RESULTS}

Achatina fulica was detected in anthropogenic environments, especially in those with great availability of food and shelter ( $82 \%$ of evaluated sites). Of the 90 sites analyzed, $73(81.1 \%)$ had mollusks with nematode larvae, and, of these, 52 (71.2\%)

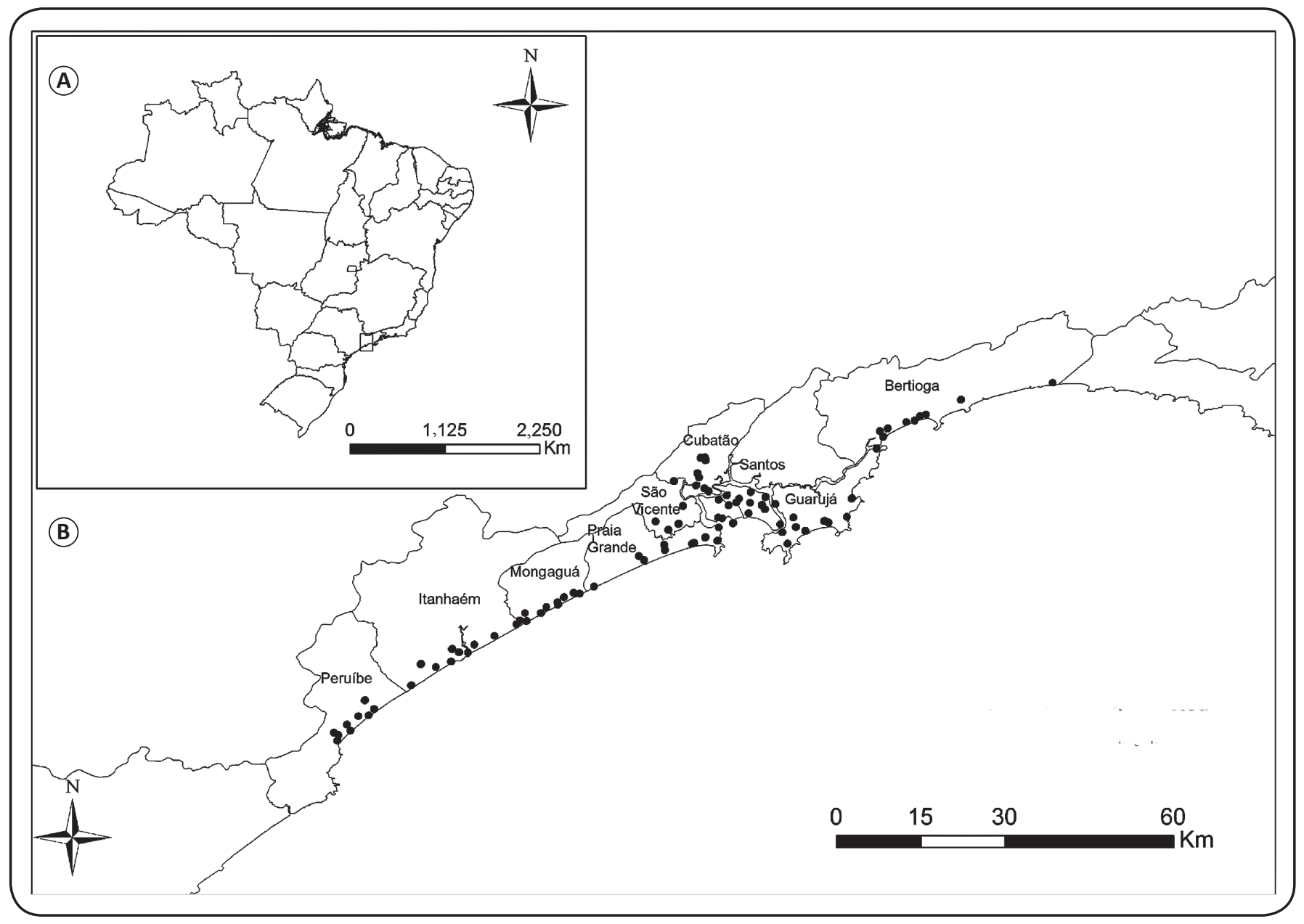

FIGURE 1 - A: Location of the study area and B: collection points in the municipalities comprising Baixada Santista, São Paulo, Brazil. 
were infected with $A$. cantonensis. Of the 540 mollusks, 204 (37.7\%) had nematode larvae, of which, 117 (57.3\%) were infected with $A$. cantonensis (21.6\% of the total) (Table 1). The prevalence of $A$. cantonensis infection in A. fulica for each municipality and the absolute number of parasite loads per mollusk are shown in Table 2.

The results were negative for the presence of $A$. costaricensis. Spatial analysis showed that the percentage of A. fulica infected with $A$. cantonensis in Baixada Santista had a random distribution, characterized by the absence of areas with much higher or much smaller infection percentages within the region $(\mathrm{I}=1: 38 ; \mathrm{p}=0.0957)$.

Morphological and morphometric analyses revealed that the larvae showed filiform bodies, striated cuticles in the transverse direction with rounded anterior ends showing two well-developed structures in the form of buttons and another in the form of a rod, followed by a long esophagus (Figure 2). The results of the morphological analyses of second-stage larvae (L2) and L3 of A. cantonensis are shown in Table 3.

\section{DIscussion}

Several snails play roles as intermediate hosts for A. cantonensis. Among them, the giant African snail A. fulica is one of the most important due to its abundance and occupation in different ecosystems. In this study, among $540 \mathrm{~A}$. fulica specimens analyzed, $204(37.8 \%)$ were found to contain nematodes, a value similar to that obtained by Rocco ${ }^{39}$, who reported a rate of $34.2 \%$. In both studies, specimens were obtained in anthropic environments where snails probably lived with small rodents, which is critical for the maintenance of parasites in the environment.

Recovered A. cantonensis larvae presented two morphotypes that were visually classified by morphometry and morphology as larval stages 2 and 3 (L2 and L3). Although the detail of the tail ending in a fine tip is a typical feature of the species, it cannot be used alone as a precise taxonomic identification factor $^{37}$; however, L3 presented measures compatible with those obtained by $\mathrm{Ash}^{37}$ and Thiengo ${ }^{11}$ (Table 3).

$\mathrm{Lv}^{10}$ found that, before the second molting, the main characteristics of L2 were similar to those of L3, as shown in Figure 2, which were two structures, similar to buttons and rods in shape. The founding of these two larval stages in the same snails is probably due to constant reinfections of the mollusk in the natural environment and to the method by which the analyzed material was obtained, in which the entire contents of the soft parts were processed.

Molecular analysis revealed the presence of A. fulica that were naturally infected with $A$. cantonensis in urban areas of the nine municipalities of the Baixada Santista region, with an infection rate of $21.7 \%$. The variation of this rate is broad and has been observed in several municipalities, such as São Gonçalo (35.4\%) and Barra do Piraí (10.3\%), both in the State of Rio de Janeiro and Joinville/SC $(27.4 \%)^{12}$, China (13.4\% and $28.4 \%)^{40,41}$, Pernambuco $(42 \%)^{11}$, and Japan $(52.79 \%)^{42}$. The climatic characteristics of Baixada Santista are appropriate

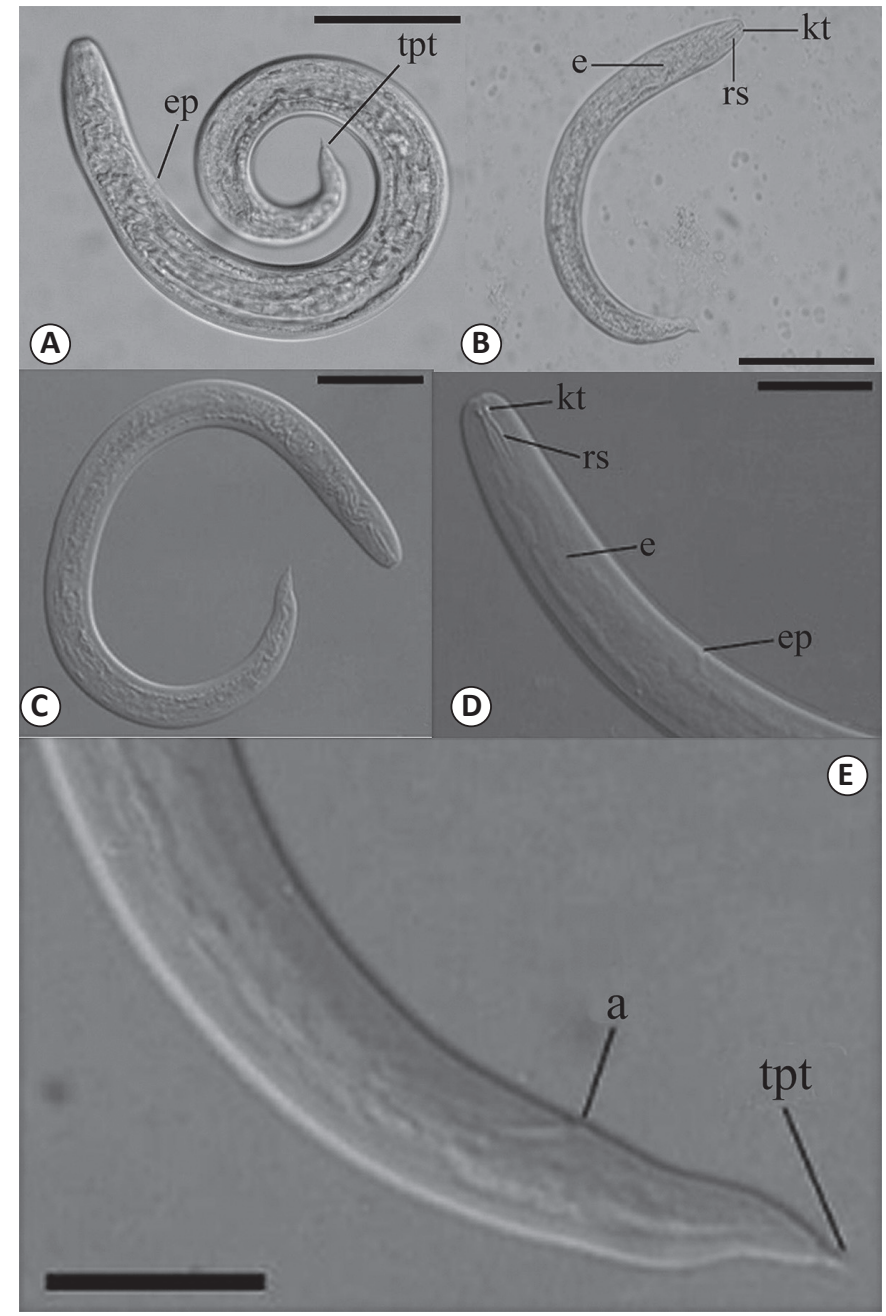

FIGURE 2 - Angiostrongylus cantonensis isolated from Achatina fulica. (A, B) Second-stage larvae (L2): scale, 50 $\mu \mathrm{m}$; (C, D) Third-stage larvae (L3): scale, $25 \mu \mathrm{m}$; (E) Anterior end of L3 larvae showing anus and tail with pointed tip: scale, $25 \mu \mathrm{m}$. Legend: kt: knob-like tips; rs: a rod-like structure; e: esophagus; ep: excretory pore. Posterior end showing: tpt: a tail with a pointed tip; a: anus.

for the development of A. fulica and A. cantonensis. In fact, Ishii ${ }^{43}$ has observed that the $\mathrm{L} 3$ of $A$. cantonensis develop better at temperatures ranging from $20^{\circ} \mathrm{C}$ to $30^{\circ} \mathrm{C}$. In addition to environmental factors such as temperature, variations in the infection rate can be influenced by biological cycle dynamics of the parasite in its hosts, by the population density of mollusks and rodents, and by biological characteristics ${ }^{22,42,44}$.

These results indicate the need for more attention to this emerging parasite through awareness campaigns for local and medical communities, the development of a health surveillance system, improved health education, and the distribution of information about the management action adapted to each reality, since $82 \%$ of the analyzed wastelands had some type of garbage or rubble. Studies on the distribution of intermediate and paratenic hosts in areas near houses and the parasite-host compatibility should be investigated to improve understanding of transmission dynamics. In Brazil, there have been few 
TABLE 1

Prevalence of nematode larvae and Angiostrongylus cantonensis in Achatina fulica mollusks in the nine municipalities comprising Baixada Santista, São Paulo, Brazil ( $\mathrm{n}=540 ; 60$ /municipality).

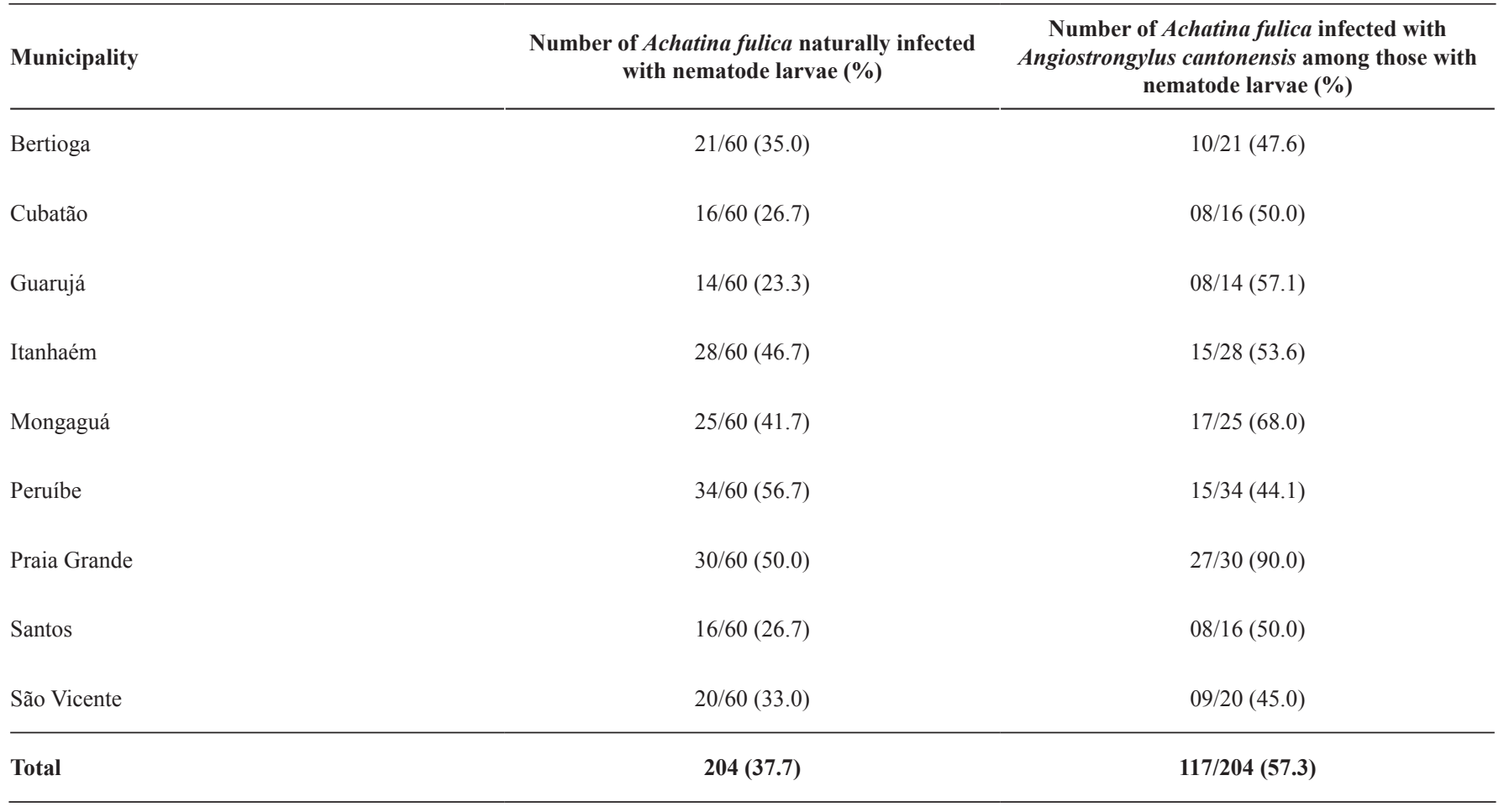

TABLE 2

Prevalence of infection by Angiostrongylus cantonensis in Achatina fulica by each municipality and the absolute number of parasitic loads per snail.

\begin{tabular}{|c|c|c|c|}
\hline Bertioga & 60 & $10(16.7)$ & $5 ; 7 ; 18 ; 36 ; 52 ; 98 ; 113 ; 148 ; 274 ; 9,723$ \\
\hline Cubatão & 60 & $8(13.3)$ & $4 ; 5 ; 17 ; 22 ; 30 ; 53 ; 82 ; 147$ \\
\hline Guarujá & 60 & $8(13.3)$ & $6 ; 11 ; 36 ; 187 ; 526 ; 703 ; 1,907 ; 2,407$ \\
\hline Mongaguá & 60 & $17(28.3)$ & $\begin{array}{l}6 ; 6 ; 7 ; 21 ; 21 ; 23 ; 30 ; 49 ; 62 ; 106 ; 110 \\
131 ; 349 ; 362 ; 448 ; 1,070 ; 3,213\end{array}$ \\
\hline Peruíbe & 60 & $15(25.0)$ & $\begin{array}{l}1 ; 3 ; 4 ; 4 ; 5 ; 8 ; 23 ; 27 ; 27 ; 66 ; 477 ; 937 \\
1,251 ; 1,302 ; 1,508\end{array}$ \\
\hline Santos & 60 & $8(13.3)$ & $1 ; 8 ; 12 ; 24 ; 281 ; 632 ; 1,328 ; 1,675$ \\
\hline São Vicente & 60 & $9(15.0)$ & $6 ; 14 ; 54 ; 61 ; 69 ; 160 ; 193 ; 285 ; 2,509$ \\
\hline
\end{tabular}




\section{TABLE 3}

Measurements $(\mu \mathrm{m})$ of second- and third-stage larvae and tail characteristics of Angiostrongylus cantonensis retrieved from naturally infected Achatina fulica.

L2

L3

\begin{tabular}{|c|c|c|c|c|}
\hline \multirow{2}{*}{ Characteristics } & \multirow[b]{2}{*}{$\begin{array}{c}\text { mean } \pm \\
\text { standard deviation }\end{array}$} & & & \\
\hline & & variation & $\begin{array}{c}\text { mean } \pm \\
\text { standard deviation }\end{array}$ & variation \\
\hline Body length & $358.2 \pm 27.8$ & $299.5-399.2$ & $450.8 \pm 23.5$ & $410.5-493.6$ \\
\hline Width & $26.4 \pm 2.6$ & $21.9-34.5$ & $21.1 \pm 5.5$ & $13.1-38.5$ \\
\hline Excretory pore & $61.9 \pm 7.6$ & $53.9-89.9$ & $86.0 \pm 4.3$ & $77.9-93.2$ \\
\hline Tail length & $29.1 \pm 3.4$ & $21.2-39.7$ & $35.3 \pm 3.8$ & $28.8-44.6$ \\
\hline Termination of tail & Tapered & & Tapered & \\
\hline
\end{tabular}

L2: second-stage larvae; L3: third-stage larvae.

studies on the action of $A$. fulica and other species of mollusks as intermediate hosts of $A$. cantonensis and their role in public health. For example, previous studies have shown the presence of other species naturally infected with $A$. cantonensis in addition to A. fulica in Brazil, such as Bradybaena similares, Subulina octona, Sarasinula marginata, and Sarasinula linguaeformis ${ }^{9,11-14}$.

Most animal populations have aggregate spatial distribution patterns, generally owing to the distribution and supply of resources in the environment ${ }^{45}$. In this study, a regular spatial distribution pattern was observed, which is quite rare. The probability is that this distribution was due to the presence of high populations of $A$. fulica in urban areas related to their high adaptability, which makes it not a limiting resource of the A. cantonensis distribution. Furthermore, as the parasite can be found in different species of intermediate hosts, its spatial distribution becomes more regular. These data are especially useful and can be used by public health authorities to establish policies related to surveillance and planning of preventive actions. Isolated cases of eosinophilic meningoencephalitis have recently been reported in Brazil ${ }^{9,11,14,15,46,47}$. Thus, it is plausible that $A$. cantonensis continues to spread to new regions, increasing the risk of eosinophilic meningoencephalitis in humans.

\section{Conflict of interest}

The authors declare that there is no conflict of interest.

\section{Acknowledgements}

To Biologist Aparecido Guerino for helping in the collections of molluses and to Prof Dr Marcos Antonio de Oliveira for giving the LABIMES (Laboratory of Molecular Biology and Structural) from the Biosciences Institute for molecular analysis.

\section{Financial support}

This work was supported by the Fundação de Amparo à Pesquisa do Estado de São Paulo (FAPESP), Process number: 2011/05893-8.

\section{REFERENCES}

1. Morera P. Life history and redescription of Angiostrongylus costaricensis Morera and Céspedes. Am J Trop Med Hyg. 1973;22(5):613-21.

2. Alicata JE. Angiostrongylus cantonensis (Nematoda: Metastrongylidae) as a causative agent of eosinophilic meningits of man in Hawaii and Tahiti. Can J Zool. 2011;40(1):5-8.

3. Pien FD, Pien BC. Angiostrongylus cantonensis eosinophilic meningitis. Int J Infect Dis. 1999;3(3):161-3.

4. Prociv P, Spratt DM, Carlisle MS. Neuro-angiostrongyliasis: unresolved issues. Int J Parasitol. 2000;30(12-13):1295-1303.

5. Lindo JF, Waugh C, Hall J, Cunningham-Myrie C, Ashley D, Eberhard ML, et al. Enzootic Angiostrongylus cantonensis in rats and snails after an outbreak of human eosinophilic meningitis, Jamaica. Emerg Infect Dis. 2002;8(3):324-6.

6. Raccurt CP, Blaise J, Durette-Desset MC. Presence of Angiostrongylus cantonensis in Haiti. Trop Med Int Healt. 2003;8(5):423-6.

7. Lai CH, Yen CM, Chin C, Chung HC, Kuo HC, Lin HH. Eosinophilic meningitis caused by Angiostrongylus cantonensis after ingestion of raw frogs. Am J Trop Med Hyg. 2007;76(2):399-402.

8. Kliks MM, Palumbo NE. Eosinophilic meningitis beyond the Pacific Basin: the global dispersal of a peridomestic zoonosis caused by Angiostrongylus cantonensis, the nematode lungworm of rats. Soc Sci Med. 1992;34(2):199-212.

9. Caldeira RL, Mendonça CLGF, Goveia CO, Lenzi HL, GraeffTeixeira C, Lima WS, et al. First record of molluscs naturally infected with Angiostrongylus cantonensis (Chen, 1935) (Nematoda: Metastrongylidae) in Brazil. Mem Inst Oswaldo Cruz. 2007;102(7):887-9. 
10. Lv S, Zhang Y, Liu HX, Zhang CW, Steinmann P, Zhou XN, et al. Angiostrongylus cantonensis: morphological and behavioral investigation within the freshwater snail Pomacea canaliculata. Parasitol Res. 2009;104(6):1351-9.

11. Thiengo SC, Maldonado A, Mota EM, Torres EJL, Caldeira R, Carvalho OS, et al. The giant African snail Achatina fulica as natural intermediate host of Angiostrongylus cantonensis in Pernambuco, northeast Brazil. Acta Trop. 2010;115(3):194-9.

12. Maldonado Jr A, Simões RO, Oliveira APM, Motta EM, Fernandez MA, Pereira ZM, et al. First report of Angiostrongylus cantonensis (Nematoda: Metastrongylidae) in Achatina fulica (Mollusca: Gastropoda) from Southeast and South Brazil. Mem Inst Oswaldo Cruz. 2010;105(7):938-41.

13. Carvalho OS, Scholte RGC, Mendonça CLF, Passos LKJ, Caldeira RL. Angiostrongylus cantonensis (Nematoda: Metastrongylidae) in molluscs from harbour areas in Brazil. Mem Inst Oswaldo Cruz. 2012;107(6):740-6.

14. Espírito-Santo MCC, Pinto PLS, Mota DJG, Gryschek RCB. The first of Angiostrongylus cantonensis eosinophilic meningitis diagnosed in the city of São Paulo, Brazil. Rev Inst Med Trop Sao Paulo. 2013;55(2):129-32.

15. Ciaravolo RMC, Pinto PLS, Mota DJG. Meningite eosinofílica e a infecção por Angiostrongylus cantonensis: um agravo emergente no Brasil. Vector Inf Tec Cient SUCEN. 2010;8:7-8.

16. Cognato BB, Morassutti AL, Silva ACA, Graeff-Teixeira C. First report of Angiostrongylus cantonensis in Porto Alegre, State of Rio Grande do Sul, Southern Brazil. Rev Soc Bras Med Trop. 2013;46(5):664-5.

17. Moreira VLC, Giese EG, Melo FTV, Simões RO, Thiengo SC, Maldonado Jr A, et al. Endemic angiostrongyliasis in the Brazilian Amazon: natural parasitism of Angiostrongylus cantonensis in Rattus rattus and $R$. norvegicus, and sympatric giant African land snails, Achatina fulica. Acta Trop. 2013;125(1):90-7.

18. Rachford FW. Potential intermediate and paratenic hosts for Angiostrongylus cantonensis. J Parasitol. 1975;61(6):1117-9.

19. Ash LR. Observations on the role of mollusks and planarians in the transmission of Angiostrongylus cantonensis infection to man New Caledonia. Rev Biol Trop. 1976;24(1):163-74.

20. Lv S, Zhang Y, Steinmann P, Zhou XN. Emerging angiostrongyliasis in Mainland China. Emerg Infect Dis. 2008;14(1):161-4.

21. Panackel C, Vishad G, Cherian K, Vijayakumar K, Sharma RN. Eosinophilic meningitis due to Angiostrongylus cantonensis. Indian J Med Microbiol. 2006;24(3):220-1.

22. Wang QP, Lai DH, Zhu XQ, Chen XG, Lun ZR. Human angiostrongyliasis. Lancet Infect Dis. 2008;8(10):621-30.

23. Hughes PA, Magnet AD, Fishbain JT. Eosinophilic meningitis: a case series report and review of the literature. Mil Med. 2003;168(10):817-21.

24. Chotmongkol V, Sawadpanitch K, Sawanyawisuth K, Louhawilai S, Limpawattana P. Treatment of eosinophilic meningitis with a combination of prednisolone and mebendazole. Am J Trop Med Hyg. 2006;74(6):1122-4.

25. Alicata JE. Biology and distribution of the rat lungworm, Angiostrongylus cantonensis, and its relationship to eosinophilic meningoencephalitis and other neurological disorders of man and animals. Adv Parasitol. 1965;3:223-48.

26. Tokiwa T, Hashimoto $T$, Yabe $T$, Komatsu N, Akao N, Ohta N. First report of Angiostrongylus cantonensis (Nematoda: Angiostrongylidae) infections in invasive Rodents from five Islands of the Ogasawara Archipelago, Japan. Plos One. 2013;8(8):e-70729.
27. Simião MC, Fischer ML. Estimativa e inferências do método de controle do molusco exótico Achatina fulica Bowdich 1822 (Stilommatophora; Achatinidae) em Pontal do Paraná, Litoral do Estado do Paraná. Cad Biodivers. 2004;4(2):74-83.

28. Fischer ML, Costa LCM. O caramujo gigante africano Achatina fulica no Brasil. $1^{\text {st }}$ edition. Curitiba/PR: Editora Champagnat; 2010. $269 \mathrm{p}$.

29. Santana Teles HM, Vaz JF, Fontes LR, Domingos MF. Registro de Achatina fulica Bowdich, 1822 (Mollusca, Gastropoda) no Brasil: caramujo hospedeiro intermediário da angiostrongilíase. Rev Saúde Pública. 1997;31(3):310-2.

30. Vasconcelos MC, Pile E. Ocorrência de Achatina fulica no Vale do Paraíba, Estado do Rio de Janeiro, Brasil. Rev Saúde Pública. 2001;35(6):582-4.

31. Oliveira JCS, Corrêa KJG, Vasconcelos HCG. Ocorrência de Achatina fulica (Mollusca: Pulmonata: Achatinidae) em três bairros da cidade de Santana, Amapá. Biota Amazônica. 2013;3(1):9-12.

32. Simone LRL. Land and freshwater molluses of Brazil. São Paulo: EGB/FAPESP; 2006. 390p.

33. Wallace GD, Rosen L. Techniques for recovering and identifying larvae of Angiostrongylus cantonensis. Malacologia. 1969;7:427-38.

34. Moraes RG. Contribuição para o estudo do Strongyloides stercoralis e da estrongiloidíase no Brasil. Rev Serv Esp Saúde Públ. 1948;1:507-624.

35. Gasser RB, Chilton NB, Hoste H, Beveridge I. Rapid sequencing of rDNA from single worms and eggs of parasitic helminths. Nucleic Acids Res. 1993;21(10):2525-6.

36. Caldeira RL, Carvalho OS, Mendonça CLFG, Graeff-Teixeira C, Silva MCF, Ben R, et al. Molecular differentiation of Angiostrongylus costaricensis, $A$. cantonensis and $A$. vasorum by polymerase chain reaction and restriction fragment length polymorphism. Mem Inst Oswaldo Cruz. 2003;98(8):1039-43.

37. Ash LR. Diagnostic morphology of the third-stage larvae of Angiostrongylus cantonensis, Angiostrongylus vasorum, Aelurostrongylus abstrusus, and Anafilaroides rostratus (Nematoda: Metastrongyloidea). J Parasitol. 1970;56(2):249-53.

38. Perry JN. Spatial analysis by distance indices. J Anim Ecol. 1995;64:303-14.

39. Rocco SC. Infecção natural de nematódeos parasitas em Achatina fulica Ferussac (Gigante africano) (Gastropoda: Pulmonata: Stylommatophora) relacionada com as condições sanitárias em vida livre e em criações comerciais no Estado de São Paulo. Tese de Doutorado. São Paulo: Coordenadoria de Controle de Doenças da Secretaria de Estado da Saúde de São Paulo; 2007. 140p.

40. Lv S, Zhang Y, Liu HX, Hu L, Yang K, Steinmann P, et al. Invasive snails and an emerging infectious disease: results from the first national survey on Angiostrongylus cantonensis in China. Plos Negl Trop Dis. 2009;3(2):e368. doi: 10.1371/journal.pntd.0000368.

41. Hu X, Du J, Tong C, Wang S, Liu J, Li Y, et al. Epidemic status of Angiostrongylus cantonensis in Hainan Island, China. Asian Pac J Trop Med. 2011 4(4):275-7.

42. Noda S, Uchikawa R, Matayoshi S, Watanabe Y, Sato A. Observations on the transmission of Angiostrongylus cantonensis from snail to rodent. J Helminthol. 1987;61(3):241-6.

43. Ishii AI. Effects of temperature on the larval development of Angiostrongylus cantonensis in intermediate host, Biomphalaria glabrata. Z Parasitenkd. 1984;70(3):375-9.

44. Monte TCC, Gentile R, Garcia J, Mota E, Santos JN, Maldonado Júnior A. Brazilian Angiostrongylus cantonensis haplotypes, ac8 
and ac9, have two diferente biological and morphological profiles. Mem Inst Oswaldo Cruz. 2014;109(8):1057-63.

45. Krebs CJ. Ecological methodology. $3^{\text {nd }}$ edition. New York (NY): Addison-Wesley Educational Publishers; 2014.

46. Lima ARMC, Mesquita SD, Santos SS, Aquino ERP, Rosa LRS, Duarte FS, et al. Alicata disease; neuroinfestation by
Angiostrongylus cantonensis in Recife, Pernambuco, Brazil. Arq Neuropsiquiatr. 2009;67(4):1093-96.

47. Morassutti AL, Thiengo SC, Fernandez M, Sawanyawisuth K, Graeff-Teixeira C. Eosinophilic meningitis caused by Angiostrongylus cantonensis: an emergent disease in Brazil. Mem Inst Oswaldo Cruz. 2014;109(4):399-407. 